\title{
Antimicrobial activity in pit and fissure sealants: a systematic review
}

\author{
- Izabela Ferreira Department of Dental Materials and Prosthodontics, Ribeirão Preto Dental School, University of \\ São Paulo (USP), Ribeirão Preto, Brazil • Thaisa Theodoro de Oliveira Department of Dental Materials and Prosthodontics, \\ Ribeirão Preto Dental School, University of São Paulo (USP), Ribeirão Preto, Brazil • Andréa Cândido dos Reis \\ Department of Dental Materials and Prosthodontics, Ribeirão Preto Dental School, University of São Paulo (USP), \\ Ribeirão Preto, Brazil
}

ABSTRACT | Objective: This study aimed to systematically review the literature about sealants modified with materials to promote antimicrobial activity and answer the question "What is the effect of incorporating materials that promote antimicrobial activity to pit and fissure sealants?" Materials and methods: Data were collected from questions about the material incorporated, its concentration, purpose of incorporation, analyses, and conclusions obtained. The Cochrane Library, LILLACS, ScienceDirect, and PubMed databases were searched with the terms "SEALANT", "ANTIMICROBIAL", and "ANTIBACTERIAL". The selection of studies was performed in two stages. Inclusion criteria were applied via the evaluation of titles and abstracts, and exclusion criteria, via the complete reading of the studies. The adapted Joanna Briggs Institute (JBI) tool was used to analyze bias risk. Results: Due to the heterogeneity of the data found, it was impossible to perform a meta-analysis. We obtained 1389 references, including 11 of them in this review. Analysis of the studies found that modified sealants may show antimicrobial activity and alter their other properties. After applying the JBI tool, all studies showed low bias risk. Conclusion: Modified pit and fissure sealants show antimicrobial activity and altered physicochemical and mechanical properties. revisão sistemática da literatura sobre selantes modificados com materiais para promover atividade antimicrobiana para responder à questão "Qual é o efeito da incorporação de materiais que promovem atividade antimicrobiana em selantes sobre fossas e fissuras?” Materiais e métodos: Dados foram coletados a partir de questões sobre o material incorporado, sua concentração, propósito de incorporação, análises e conclusões obtidas. As bases de dados Cochrane Library, LILLACS, ScienceDirect e PubMed foram pesquisadas com os termos "SELANTE", "ANTIMCROBIAL" e "ANTIBACTERIAL". Os artigos foram selecionados em duas etapas. Critérios de inclusão foram aplicados pela avaliação de títulos e resumos e critérios de exclusão, pela completa leitura desses artigos. A ferramenta adaptada do Joanna Briggs Institute foi usada para analisar o risco de viés. Resultados: Dada a heterogeneidade dos dados encontrados, foi impossível realizar uma meta-análise. Obtivemos 1389 referências, das quais 11 foram incluídas nessa revisão. A análise dos artigos mostrou que selantes modificados podem apresentar atividade antimicrobiana e alteração de suas outras propriedades. Conclusão: Selantes alterados sobre fossas e fissuras mostram atividade antimicrobiana e propriedades físico-químicas e mecânicas alteradas.

DESCRITORES | Selantes sobre Fossas e Fissuras; Atividade Antimicrobiana, Revisão Sistemática; Materiais Dentários; Método Preventivo.

CORRESPONDING AUTHOR | • Andréa Cândido dos Reis Department of Dental Materials and Prosthodontics, Ribeirão Preto Dental School, University of São Paulo • Av. do Café, s/n Ribeirão Preto, SP, Brazil • 14040-904 E-mail: andreare73@yahoo.com.br

- Received 18112021 • Accepted 19012022.

- Dol: http://dx.doi.org/10.11606/issn.2357-8041.clrd.2022.192671. 


\section{INTRODUCTION}

The presence of acidogenic microorganisms, poor oral hygiene, diet, and teeth anatomy are the main factors for the onset of caries. ${ }^{1}$ Molars and premolars are the teeth most affected by the disease due to their complex occlusal morphology with narrow pits and fissures that harbor debris and microorganisms, hindering the mechanical action of brushing and the reach of fluorides into these regions. ${ }^{2-6}$

Applying pit and fissure sealants is an effective prevention method against the onset and progression of caries..$^{5-9}$ Such materials act as a physical barrier between teeth and the oral environment, preventing microorganisms and food from entering the vulnerable sites of occlusal surfaces, which are more susceptible to the disease..$^{3-7}$

The literature has recognized and documented the clinical success of sealants, ${ }^{2,3,7}$ mainly ensured due to their ability to remain adhered to dental structures.7,10,11 However, such treatment may be subject to failures that damage the physical barrier formed by sealants, enabling the invasion of microorganisms and fluids from the oral cavity which form caries. ${ }^{3-5}$ These failures may be related to the presence of moisture, tooth eruption stages, ${ }^{2,12}$ and characteristics of the material, such as polymerization contraction, ${ }^{5,7}$ absence of marginal adaptation, ${ }^{3}$ degradation of the oral environment, ${ }^{5,11}$ and micro infiltrations..$^{5,8,9,12}$ Moreover, if the operator makes a mistake when applying the sealant, debris and microorganisms may remain on the occlusal surface, as in cases of incipient caries. ${ }^{5}$

Currently, new technologies and biomaterials have improved products and may add beneficial properties to their use in dentistry. ${ }^{4,5}$ Antimicrobial activity, associated with pit and fissure sealants, is an important characteristic, as it strengthens the defense mechanism of these materials either by building up a physical barrier or by releasing bioactive components that reduce biofilm formation. ${ }^{4,5,8,9,11,13}$
Recent literature emphasizes that incorporating nano- and biomaterials such as silver nanoparticles, chlorhexidine, chitosan, and dimethylaminohexadecyl methacrylate not only promotes antimicrobial activity but also improves the mechanical properties of sealants, which provide the materials with a more effective preventive capacity. ${ }^{11,13}$

Thus, this study aims to carry out a systematic review of articles found in the literature which address the topic of sealants with the addition of materials capable of promoting antimicrobial activity, thus improving possible failures and their consequences for the preventive treatment of caries.

\section{MATERIAL AND METHODS}

\section{Protocol}

This systematic review was prepared in accordance with the Preferred Reporting Items for Systematic Review and Meta-Analyses for Protocols (PRISMA) to answer the question "What is the effect of incorporating materials that promote antimicrobial activity to pit and fissure sealants?”

\section{Eligibility criteria}

Articles that addressed the incorporation of materials capable of promoting antimicrobial activity to pit and fissure sealants and were published in the last five years (2015-2020) were included. Book chapters, systematic reviews, and articles addressing other subjects were excluded.

\section{Information sources and bibliographical research}

The search was carried out in the following databases: Cochrane Library, LILACS, ScienceDirect, and PubMed with the terms "SEALANT" AND "ANTIMICROBIAL" AND "ANTIBACTERIAL". Before the completion of this study, a new search 
was conducted in these databases, in which two new articles were found and included.

\section{Study selection}

The selection of studies was made in two stages. Inclusion criteria were applied by evaluating titles and abstracts. Then, the studies were read in full and the exclusion criteria were applied.

\section{Data collection and categorization}

A table with seven questions was used to collect data from the selected articles according to the objective of this study. The questions refer to the material incorporated and its concentration, purpose, analyses performed, and conclusions obtained in the studies, as shown in Table 1.

TABLE 1 | Data tabulation according to author, year, objective, materials evaluated, test, and results.

\begin{tabular}{|c|c|c|c|c|}
\hline Author, year & Objective & $\begin{array}{l}\text { Material } \\
\text { incorporated and its } \\
\text { concentration }\end{array}$ & Tests & Conclusions \\
\hline Garcia et al., $2020^{14}$ & $\begin{array}{l}\text { To add METAC to the } \\
\text { formulation of sealants } \\
\text { and check its influence } \\
\text { on their properties. }\end{array}$ & $2.5 \%$ and $5 \%$ METAC. & $\begin{array}{l}\text { Degree of conversion, } \\
\text { ultimate tensile strength, } \\
\text { micro-shear bond strength, } \\
\text { antibacterial activity, } \\
\text { cytotoxicity }\end{array}$ & $\begin{array}{c}\text { Sealants showed } \\
\text { antimicrobial activity in } \\
\text { both concentrations and } \\
\text { no changes to the other } \\
\text { properties. }\end{array}$ \\
\hline Cocco et al., $2020^{15}$ & $\begin{array}{l}\text { To evaluate pit and } \\
\text { fissure sealants } \\
\text { containing ZnM or SnM, } \\
\text { developed for easy } \\
\text { handling/application } \\
\text { and powerful anti- } \\
\text { biofilm activity. }\end{array}$ & $\begin{array}{l}2.5 \% \text { and } 5 \% \mathrm{ZnM} ; \\
2.5 \% \text { and } 5 \% \text { SnM. }\end{array}$ & $\begin{array}{l}\text { Degree of conversion, } \\
\text { micro-shear bond strength, } \\
\text { flexural strength, single- } \\
\text { and dual-species biofilm } \\
\text { model, scanning electron } \\
\text { microscopy, cytotoxicity. }\end{array}$ & $\begin{array}{c}\text { The sealant containing } 5 \% \\
\text { SnM showed antibacterial } \\
\text { activity against various oral } \\
\text { biofilms and no change to } \\
\text { its other properties. }\end{array}$ \\
\hline Hesaraki et al., $2020^{1}$ & $\begin{array}{l}\text { To evaluate the effect } \\
\text { of SrF2, YSZ, and } \\
\varepsilon \text {-PL additives on the } \\
\text { physical-mechanical and } \\
\text { antibacterial properties } \\
\text { of resin-based pit } \\
\text { and fissure sealants } \\
\text { via proper analytical } \\
\text { techniques. }\end{array}$ & $\begin{array}{c}5 \%, 10 \% \\
\text { and } 20 \% \text { SrF2; } 5 \% \\
\text { and } \\
10 \% \text { YSZ; } 0.5 \% \varepsilon-H P L\end{array}$ & $\begin{array}{l}\text { Flexural strength, } \\
\text { compressive strength, } \\
\text { scanning electron } \\
\text { microscopy, fluoride release, } \\
\text { colony-forming units, } \\
\text { cytotoxicity. }\end{array}$ & $\begin{array}{c}\text { Based on physical- } \\
\text { mechanical and } \\
\text { antibacterial properties, } \\
\text { the ideal sealant } \\
\text { contained } 5 \% \text { SrF by } \\
\text { weight, } 2.5 \% \text { YSZ by } \\
\text { weight, and } 0.5 \% \varepsilon \text {-PL by } \\
\text { weight. }\end{array}$ \\
\hline Shinonaga et al., $2015^{16}$ & $\begin{array}{c}\text { To evaluate the } \\
\text { mechanical and } \\
\text { chemical properties of } \\
\text { a novel glass ionomer } \\
\text { cement to be used as a } \\
\text { pit and fissure sealant } \\
\text { containing HAp. }\end{array}$ & $28 \% \mathrm{HAp}$ & $\begin{array}{l}\text { Flexural strength, } \\
\text { compressive strength, } \\
\text { scanning electron } \\
\text { microscopy, fluoride ion } \\
\text { release Adenosine-5'- } \\
\text { triphosphate luminescence }\end{array}$ & $\begin{array}{l}\text { HAp showed antimicrobial } \\
\text { activity, but after } 4 \text { hours, } \\
\text { its activity decreased, } \\
\text { reaching lower numbers } \\
\text { than the control. } \\
\text { Resistance to flexion } \\
\text { increased over time. }\end{array}$ \\
\hline Hamilton et al., $2015^{11}$ & $\begin{array}{l}\text { To develop resin-based } \\
\text { experimental dental } \\
\text { sealants containing } \\
\mathrm{N} 6 \text { and } \mathrm{CH} \text { fibers in an } \\
\text { attempt to improve its } \\
\text { physical-mechanical } \\
\text { properties and provide } \\
\text { an antibacterial effect. }\end{array}$ & $\begin{array}{l}1 \%, 2.5 \% \text { and } 5 \% \mathrm{~N} 6 \\
1 \%, 2.5 \% \text { and } 5 \% \mathrm{CH}\end{array}$ & $\begin{array}{c}\text { Flexural strength, Vickers } \\
\text { microhardness, agar } \\
\text { diffusion }\end{array}$ & $\begin{array}{l}\text { There was no formation } \\
\text { of inhibition halos. The } \\
\text { groups incorporated with } \\
\mathrm{CH} \text { showed higher Vickers } \\
\text { microhardness values and } \\
\text { better flexural strength } \\
\text { than the 5\% N6 group. }\end{array}$ \\
\hline
\end{tabular}


Tabela 3 | continuação

\begin{tabular}{|c|c|c|c|c|}
\hline Author, year & Objective & $\begin{array}{c}\text { Material } \\
\text { incorporated and its } \\
\text { concentration }\end{array}$ & Tests & Conclusions \\
\hline Shanmugaavel et al., $2015^{13}$ & $\begin{array}{l}\text { To evaluate the effect of } \\
\text { adding } 1 \% \mathrm{CHX} \text { on the } \\
\text { antibacterial activity and } \\
\text { mechanical properties of } \\
\text { sealants. }\end{array}$ & $1 \% \mathrm{CHX}$ & $\begin{array}{c}\text { Agar diffusion, compressive } \\
\text { strength, diametral tensile } \\
\text { strength. }\end{array}$ & $\begin{array}{l}\text { CHX showed an } \\
\text { antimicrobial effectiveness } \\
\text { that was unchanged for } 30 \\
\text { days and had no effect on } \\
\text { the other properties of the } \\
\text { sealants. }\end{array}$ \\
\hline Rajabnia et al., $201^{61} 7$ & $\begin{array}{l}\text { To assess the inhibitory } \\
\text { effect of sealants } \\
\text { containing } \mathrm{CH} \text { against } \\
\text { Streptococcus mutans. }\end{array}$ & $\begin{array}{c}1 \%, 2 \% \\
3 \%, 4 \% \text { and } 5 \% \mathrm{CH} .\end{array}$ & $\begin{array}{l}\text { Direct contact test with } \\
\text { S. Mutans and minimum } \\
\text { inhibitory concentration }\end{array}$ & $\begin{array}{l}\text { Better results in the group } \\
\text { with } 2.5 \% \mathrm{CH} \text {, with the } \\
\text { highest activity between } \\
\text { the first and third month. } \\
\text { The minimum inhibitory } \\
\text { concentration was } 2 \% \text {. }\end{array}$ \\
\hline Yu et al., $2016^{5}$ & $\begin{array}{l}\text { To assess the inhibitory } \\
\text { effect of a MAE-DB- } \\
\text { incorporated sealant } \\
\text { against Streptococcus } \\
\text { mutans. }\end{array}$ & 4\% MAE-DB & $\begin{array}{c}\text { Absorbance and CFU, } \\
\text { laser scanning confocal } \\
\text { microscopy. }\end{array}$ & $\begin{array}{c}\text { MAE-DB showed } \\
\text { antimicrobial effectiveness } \\
\text { and continued to do so after } \\
\text { six months of aging without } \\
\text { decrease to its capacity. }\end{array}$ \\
\hline Ibrahim et al., $2019^{4}$ & $\begin{array}{l}\text { To evaluate the effect } \\
\text { of DMAHDM on the } \\
\text { cariogenic pathogenicity } \\
\text { of Streptococcus } \\
\text { mutans biofilms. }\end{array}$ & $\begin{array}{c}5 \% \text { DMAHDM; } 20 \% \\
\text { NACP }\end{array}$ & $\begin{array}{c}\text { Biofilm formation, CFU, MTT, } \\
\text { confocal laser scanning } \\
\text { microscopy. }\end{array}$ & $\begin{array}{l}\text { Additives significantly } \\
\text { reduced S. mutans biofilm } \\
\text { formation due to their } \\
\text { detrimental biological } \\
\text { effect. }\end{array}$ \\
\hline Garcia et al., $2019^{18}$ & $\begin{array}{c}\text { To evaluate the } \\
\text { influence of PHMGH in } \\
\text { the physicochemical } \\
\text { properties and } \\
\text { antibacterial activity of } \\
\text { an experimental sealant. }\end{array}$ & $\begin{array}{c}0.5 \%, 1 \% \text {, and } 2 \% \\
\text { PHMGH }\end{array}$ & $\begin{array}{l}\text { Degree of conversion, tensile } \\
\text { strength, direct contact } \\
\text { inhibition analysis, CFU }\end{array}$ & $\begin{array}{c}\text { Additives showed } \\
\text { antimicrobial effectiveness } \\
\text { at concentrations } \\
\text { higher than } 1 \% \text { and } \\
\text { reliable physicochemical } \\
\text { properties. }\end{array}$ \\
\hline Monteiro et al., 2020 19 & $\begin{array}{c}\text { To evaluate the } \\
\text { physicochemical } \\
\text { properties and effects } \\
\text { against S. mutans of a } \\
\text { sealant containing TAT } \\
\text { and } \alpha \text {-TCP }\end{array}$ & $2 \%$ TAT; $2 \% \alpha-\mathrm{TCP}$ & $\begin{array}{c}\text { Degree of conversion, } \\
\text { microhardness, tensile } \\
\text { strength, biofilm formation }\end{array}$ & $\begin{array}{l}\text { The sealant showed } \\
\text { antimicrobial capacity } \\
\text { and no change to } \\
\text { physicochemical } \\
\text { properties. }\end{array}$ \\
\hline
\end{tabular}

METAC: [2-(methacryloyloxy)ethyl] trimethylammonium chloride; ZnM: zinc methacrylates; SnM: di-n-butyl-dimethacrylate-tin; SrF2: synthetic strontium fluoride; YSZ: yttria-stabilized zirconia; $\varepsilon$-PL: poly- $\varepsilon$-L-lysin; Hap: porous-hydroxyapatite; N6: nylon-6; CH: chitosan; CHX: chlorhexidine digluconate; MAE-DB: 2- methacryloxylethyl dodecyl methyl ammonium bromide; DMAHDM: dimethylaminohexadecyl methacrylate; NACP: amorphous calcium phosphate; PHMGH: polyhexamethylene guanidine hydrochloride; TAT: 1,3,5-tri acryloyl hexahydro-1,3,5-triazine; $\alpha$-TCP: $\alpha$-tricalcium phosphate.

\section{Analysis of bias risk}

The Joanna Briggs Institute (JBI) checklist for quasi-experimental studies (non-randomized experimental studies) was adapted to assess bias risk. ${ }^{20}$ To rate the methodological quality of the studies, each question was scored by "yes", "no", and "uncertain”, so when all questions were answered with "yes", studies were considered high-quality ones (low bias risk), whereas studies that had six to seven "yes", moderatequality ones (medium bias risk), and with five or fewer "yes", low-quality ones (high bias risk). The analysis was performed by the RevMan 5.3 software.

\section{Data synthesis}

In this study, it was impossible to conduct a metaanalysis due to the heterogeneity of the data found. 


\section{RESULTS}

\section{Study description}

In total, 1389 articles were found in the databases. After ruling out duplicates and applying our exclusion criteria, 16 articles were read in full, nine of which were included in the study. After this step, new literature search was conducted, finding two other articles that were included in the final sample, totaling 11 articles evaluated, as Figure 1 shows.

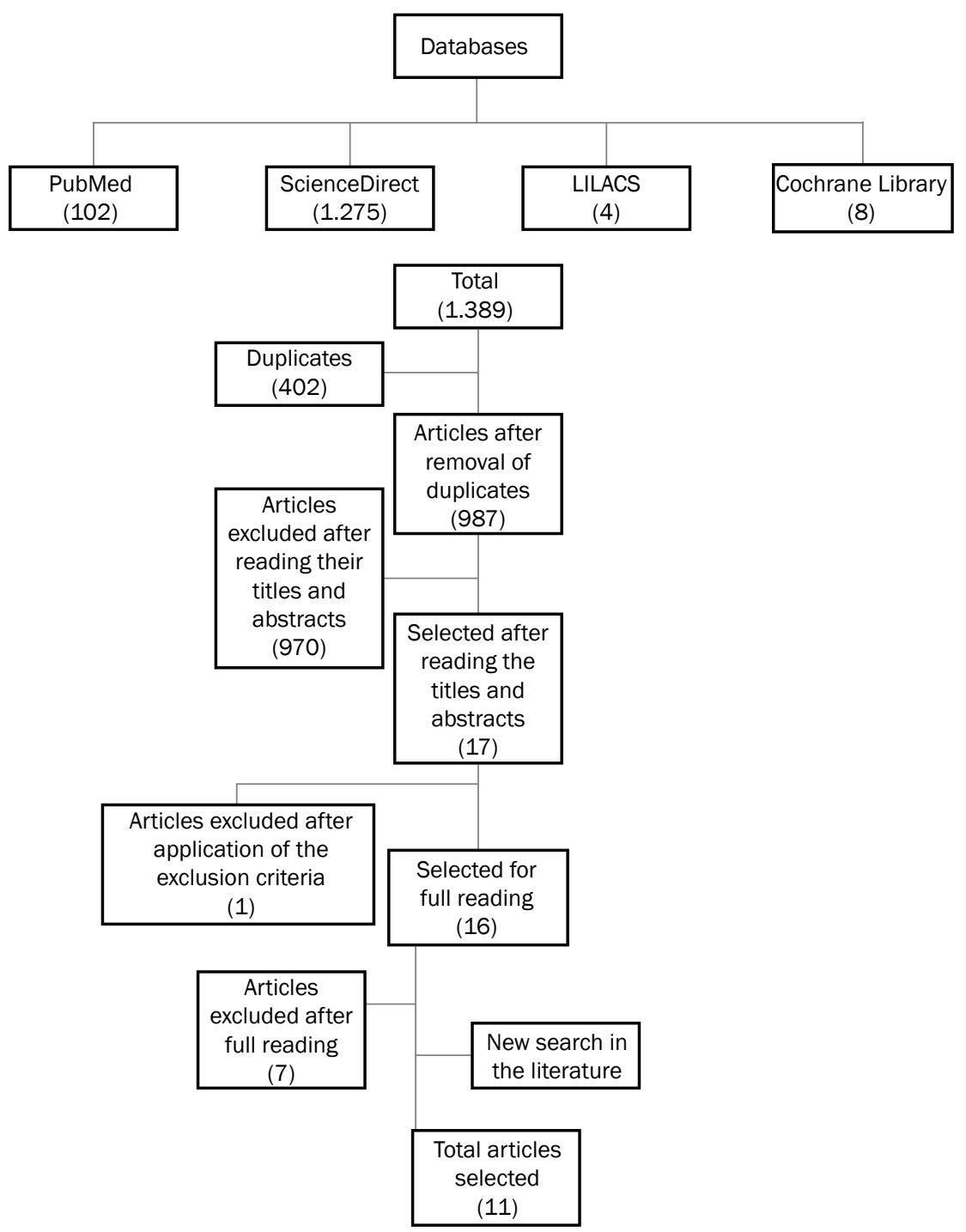

FIGURE 1 | Flow diagram of the literature search and selection criteria.

\section{Bias rísk}

We evaluated bias risk and the 11 studies failed to make clear the number of investigators or their training to conduct these studies. Therefore, we marked the question "Were outcomes reliably measured?" as uncertain (Figure 2 and 3 ). However, we ignored this question in estimating bias risk, which allowed us to rate these studies as methodologically sound (low bias risk) (Table 2). 
Does the study make clear what is the 'cause' and what is the 'effect' (i.e., there is no confusion about which variable comes first) Were specimens included in any similar comparison? Were specimens included in comparisons which received similar treatment/care other than the exposure or intervention of interest? Was there a control group? Were there multiple measurements of the outcome both before and after the intervention/exposure? Were the outcomes of participants included in any comparisons measured in the same way? Were outcomes reliably measured? Did the authors use appropriate statistical analyses?

Unclear bias risk

High bias risk

FIGURE 2 | Qualitative analysis with the adapted checklist for quasi-experimental studies of the Joanna Briggs Institute.
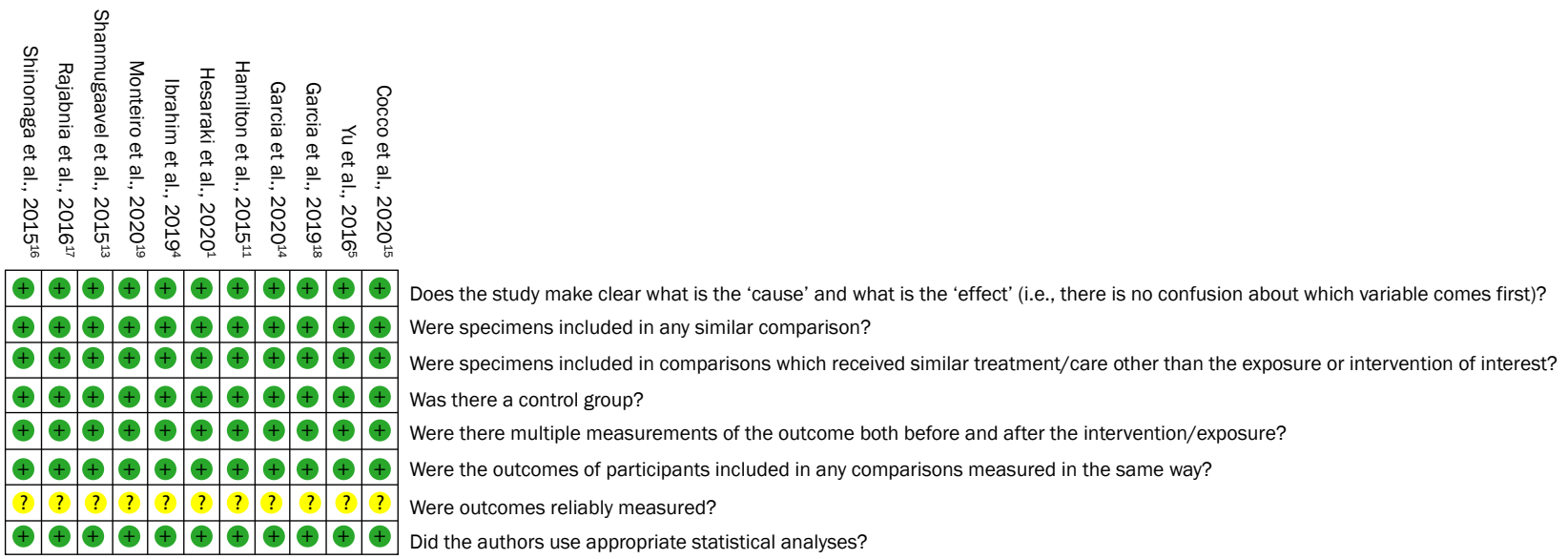

FIGURE 3 | Qualitative analysis of the studies included by the adapted checklist for quasi-experimental studies of the Joanna Briggs Institute.

TABLE 2 | Bias risk classification of the studies included in our systematic review.

\begin{tabular}{|c|c|}
\hline Author, year & Bias risk classification \\
\hline Garcia et al., $2020^{14}$ & Low risk \\
\hline Cocco et al., $2020^{15}$ & Low risk \\
\hline Hesaraki et al., $2020^{1}$ & Low risk \\
\hline Shinonaga et al., $2015^{16}$ & Low risk \\
\hline Hamilton et al., $2015^{11}$ & Low risk \\
\hline Shanmugaavel et al., $2015^{13}$ & Low risk \\
\hline Rajabnia et al., $2016^{17}$ & Low risk \\
\hline Yu et al., $2016^{5}$ & Low risk \\
\hline Ibrahim et al., $2019^{4}$ & Low risk \\
\hline Garcia et al., $2019^{18}$ & Low risk \\
\hline Monteiro et al., $2020^{19}$ & Low risk \\
\hline
\end{tabular}

\section{Incorporation of materials}

Among the selected articles, authors incorporated several materials into pit and fissure sealants to provide them with antimicrobial activity, such as chitosan, ${ }^{11,17}$ chlorhexidine gluconate, ${ }^{13}$ porous hydroxyapatite, ${ }^{16}$ polyhexamethylene guanidine hydrochloride (PHMGH), ${ }^{18} \mathrm{SrF}_{2}$ and YSZ nanoparticles and poly$\varepsilon$-L-lysin and the monomers 2-methacryloxylethyl dodecyl methyl ammonium bromide (MAE-DB), 5 dimethylaminohexadecyl methacrylate (DMAHDM), ${ }^{4}$ 
[2-(methacryloxy)ethyl] trimethylammonium chloride (METAC), ${ }^{14}$ di-n-butyl-dimethacrylate-tin, ${ }^{15}$ and 1,3,5- tri-acryloyl hexahydro-1,3,5-triazine (TAT) and $\alpha$-tricalcium phosphate (-TCP). ${ }^{19}$

Studies used resin ${ }^{1,4,5,11,14,15,17-19}$ and ionomers as their main types of sealants. ${ }^{13,16}$ The materials incorporated were added by mass to powders ${ }^{16,17}$ or liquids. ${ }^{1,11,13}$ However, percentages differed. Studies employed several techniques to combine their components, such as glass plates and plastic spatulas, ${ }^{1,17}$ high speed dispersion, ${ }^{16}$ and magnetic stirring, ${ }^{11}$ which enabled material homogeneity. In all experiments, authors made specimens from mixtures to analyze their biological, physical, chemical, and mechanical properties.

All the selected articles aimed at promoting antimicrobial activity. However, some studies only evaluated this aspect, ${ }^{5,13,17}$ whereas others also analyzed the physical, chemical, and mechanical properties of the modified sealants. . $^{1,4,11,14-19}$

\section{Biological analysis}

The biological analyses performed in the selected studies were cytotoxicity, ${ }^{1,14,15}$ colonyforming units (CFU), ${ }^{4,5,14}$ agar diffusion, ${ }^{11,13}$ biofilm formation, ${ }^{4,5,14,15,18,19}$ and direct contact. ${ }^{17}$ All analyses for antimicrobial activity used Streptococcus mutans.

Some studies evaluated action time, i.e., how long the modified sealants showed antimicrobial activity after incorporation. ${ }^{5,13,16,17}$ Authors found unchanged antimicrobial capacity for 30,90 , and 180 days after incorporation, ${ }^{5,13,17}$ though one observed a decrease in capacity after four hours of incorporation. ${ }^{16}$

Thus, most authors had success in promoting antimicrobial activity to pit and fissure sealants ${ }^{1,4,5,13-15,17-19}$ with long-term effects. ${ }^{5,13,17}$ Only one experiment failed to promote antimicrobial activity in sealants. ${ }^{11}$

\section{Physicochemical and mechanical analyses}

Authors assessed the physical properties of the modified sealants by degree of conversion analyses (DC) ${ }^{14,15,18,19}$ and scanning electron microscopy (SEM). ${ }^{1,11,16}$ Some studies that evaluated the DC showed that adding materials to the sealants may fail to change the polymerization of the material ${ }^{15,18,19}$ or affect it if a greater amount of material is added, making it slower, as reported by Garcia et al. ${ }^{14}$ Authors found, via SEM, an increase in surface roughness, as well as nanoparticles evenly distributed along surfaces. ${ }^{1,11,16}$

The chemical analysis performed in the studies was fluoride release. ${ }^{1,16}$ The studies found that, immediately after incorporation, the modified sealants had a higher fluoride release than the control. In the long term, fluoride release gradually decreased until it stabilized, but the release remained higher than in the control group.,16

Compression, ${ }^{1,13,16}$ flexural $^{1,11,15,16}$ and traction ${ }^{13,18,19}$ strength were the most prevalent mechanical analyses in the articles. In general, compressive strength was maintained or increased resistance after material incorporation..$^{1,13,16}$ In the case of flexion, studies disagreed, finding favorable $\mathrm{e}^{11,16,15}$ and unfavorable results. ${ }^{1}$ Studies found no significant changes in tensile strength. ${ }^{13,14,18}$ However, Monteiro et al. found that the good distribution of particles of the added material improved the traction of the modified sealants. ${ }^{19}$

Studies complementarily performed tests such as sorption and solubility, ${ }^{1}$ softening, ${ }^{14,18}$ polymerization contraction, ${ }^{1}$ microhardness, ${ }^{11,19}$ and micro-shear ${ }^{14,15}$. In general, studies that evaluated the physicochemical and mechanical properties of modified sealants obtained positive changes, ${ }^{11,16}$ negative changes ${ }^{1,18}$ or property maintenance..$^{13,14,15,19}$ 


\section{DISCUSSION}

This systematic review evaluated studies that incorporated materials to pit and fissure sealants to provide antimicrobial activity. This property allows the releasing of components capable of reducing biofilm formation and, consequently, secondary caries, increasing the preventive capacity of the materials. ${ }^{4,14,17}$

Thus, we aspired to critically analyze the included in vitro studies, ${ }^{1,4,5,11,13-19}$ all of which were well designed and with low bias risk for the questions adapted from the quasi-experimental (nonrandomized) study assessment tool of the Joanna Briggs Institute. We interpreted the results with caution. Moreover, the heterogeneity of the included studies made a meta-analysis impossible.

In the studies evaluated, authors incorporated different materials to the sealants, hindering data distribution and homogeneity. On the other hand, this fact shows the feasibility of the process, since the evaluated sealants allow the inclusion of different additives to their formulations with a satisfactory interaction between the components, providing a homogeneous mixture.

Most of the selected articles showed the antimicrobial activity conferred to the sealants by incorporating these materials. However, they disagreed regarding chitosan. Hamilton et al. reported no inhibition of bacterial growth, ${ }^{11}$ while Rajabnia et al. succeeded in doing so, in agreement with the study by Mahapoka et al., in which adding chitosan to the modified sealants inhibited the growth of $S$. mutans. ${ }^{17,21}$ The antimicrobial activity of chitosan depends on several factors, such as its molecular weight, degree of deacetylation, and $\mathrm{pH},{ }^{22}$ which may explain the divergent results in Hamilton et al. ${ }^{11}$

Other properties of the modified material should remain unaltered after the incorporation of a component to promote antimicrobial activity, as found in the studies by Shanmugaavel et al., Garcia et al., Cocco et al., and Monteiro et al., in which the physicochemical and mechanical properties of pit and fissure sealants failed to show statistically significant changes. ${ }^{13-15,19}$

Moreover, incorporating different materials can promote negative changes in the physicochemical and mechanical properties of sealants, as found in the studies by Garcia et al. and Hesaraki et al., who obtained, as a consequence, the reduction of material strength. This reduction may be due to the formation of agglomerates that fail to adhere properly to their surfaces or the lack of standardization in the proportions of the added material., ${ }^{1,18}$ In agreement with Nikolaidis et al., who found reduced mechanical properties after incorporating a nanomaterial, the authors reported the formation of agglomerates and lack of adequate nanoparticle distribution as factors causing the reduction of strength. ${ }^{23}$

However, Hamilton et al. and Shinonaga et al. considerably increased the strength of modified sealants after incorporating materials to confer them antimicrobial activity. This is due to proper infiltration and the distribution of the particles added to sealants, as well as the dissipation of stress along the fibers of the added materials, leading to a significant improvement in the physicochemical and mechanical properties of their sealants. ${ }^{11,16}$

Shinonaga et al. and Hesaraki et al. evaluated another important result in their studies: fluoride release from modified ionomer and resin sealants, which showed an increase in ion release into the medium. ${ }^{1,16}$ Such property in pit and fissure sealants can increase the preventive capacity of the material as fluoride neutralizes bacterial acids, promotes the formation of fluorapatite, and increases tooth remineralization in case of secondary caries. ${ }^{24-26}$ Okuyama et al. and Yasuhiro et al. showed in their studies how fluoride can adhere to enamel and dentin, helping to reduce tissue demineralization due to acid attacks from cariogenic bacteria. ${ }^{25,26}$

Hasan et al. also evaluated the release of fluoride in glass-ionomer cements (GIC) without 
incorporating any type of antimicrobial agent, resulting in decreased fluoride release as the material matured. ${ }^{24}$ Thus, the incorporation Shinonaga et al. and Hesaraki et al. strengthened the preventive capacity of the modified sealants due to the constant and increased release of these ions in the medium.

The great difference among the studies led to a difficulty in converging their results, showing, by this systematic review, that the literature offers very comprehensive studies. This hinders data synthesis, showing a lack in the literature that would enable the construction of definitive knowledge from the studies found.

\section{CONCLUSION}

Based on the results of this systematic review, we found that incorporating materials into pit and fissure sealants could confer them antimicrobial activity and change their inherent physicochemical and mechanical properties.

\section{DECLARATIONS}

The authors have no conflict of interest and did not receive any financial support for this publication.

\section{REFERENCES}

1. Hesaraki S, Karimi M, Nezafati N. The synergistic effects of SrF2 nanoparticles, YSZ nanoparticles, and poly- $\varepsilon$-L-lysin on physicomechanical, ion release, and antibacterial-cellular behavior of theflowable dental composites. Mater Sci Eng C. 2020;109:110592. Doi: https://doi.org/10.1016/j.msec.2019.110592.

2. Moreira KMS, Kantovitz KR, Aguiar JPD, Borges AFS, Pascon FM, Puppin-Rontani RM. Impact of the intermediary layer on sealant retention: a randomized 24-month clinical trial. Clin Oral Investig. 2017;21(5):1435-43. Doi: https://doi. org/10.1007/s00784-016-1890-4.

3. Kantovitz KR, Pascon FM, Nociti FH Jr, Tabchoury CPM, Puppin-Rontani RM. Inhibition of enamel mineral loss by fissure sealant: An in situ study. J Dent. 2013;41(1):42-50. Doi: http://doi.org/10.1016/j.jdent.2012.09.015

4. Ibrahim MS, Ibrahim AS, Balhaddad AA, Weir MD, Lin NJ, Tay FR, et al. A novel dental sealant containing dimethylami- nohexadecyl methacrylate suppresses the cariogenic pathogenicity of Streptococcus mutans biofilms. Int J Mol Sci. 2019;20(14):3491. Doi: https://doi.org/10.3390/ijms20143491.

5. Yu F, Yu H, Lin P, Dong Y, Zhang L, Sun X, et al. Effect of an antibacterial monomer on the antibacterial activity of a pit-and-fissure sealant. PLoS One. 2016;11(9):e0162281. Doi: https://doi.org/10.1371/journal.pone.0162281.

6. Papageorgiou SN, Dimitraki D, Kotsanos N, Bekes K, van Waes H. Performance of pit and fissure sealants according to tooth characteristics: A systematic review and metaanalysis. J Dent. 2017;6:8-17. Doi: https://doi.org/10.1016/j. jdent.2017.08.004.

7. Borges BCD, Souza-Júnior EJ, Catelan A, Lovadino JR, Santos PH, Paulillo LAMS, et al. Influence of extended light exposure time on the degree of conversion and plasticization of materials used as pit and fissure sealants. J Investig Clin Dent. 2010;1(2):151-5. Doi: https://doi.org/10.1111/j.20411626.2010.00015.x.

8. Kloukos D, Pandis N, Eliades T. In vivo bisphenol-A release from dental pit and fissure sealants: A systematic review. J Dent. 2013;41(8):659-67. Doi: http://doi.org/10.1016/j. jdent.2013.04.012

9. Paris S, Lausch J, Selje T, Dörfer CE, Meyer-Lueckel H. Comparison of sealant and infiltrant penetration into pit and fissure caries lesions in vitro. J Dent. 2014;42(4):432-8. Doi: https://doi.org/10.1016/j.jdent.2014.01.0o6.

10. Borges BCD, Bezerra GVG, Mesquita JA, Pereira MR, Aguiar FHB, Santos AJS, et al. Effect of irradiation times on the polymerization depth of contemporary fissure sealants with different opacities. Braz Oral Res. 2011;25(2):135-42. Doi: https://doi.org/10.1590/S1806-83242011000200007.

11. Hamilton MF, Otte AD, Gregory RL, Pinal R, Ferreira-Zandoná A, Bottino MC. Physicomechanical and antibacterial properties of experimental resin-based dental sealants modified with nylon- 6 and chitosan nanofibers. J Biomed Mater Res B Appl Biomater. 2015;103(8):156o-8. Doi: https://doi. org/10.1002/jbm.b.33342.

12. Fiorati-Aguiar SM, Lucisano MP, Silva LAB, Silva RAB, Spadaro ACC, Borsatto MC, et al. Mechanical, chemical and antimicrobial properties of a bisphenol A-free pit-and-fissure sealant. Am J Dent. 2018;31(6):279-84.

13. Shanmugaavel AK, Asokan S, John JB, Priya PG, Devi JG. Effect of one percent chlorhexidine addition on the antibacterial activity and mechanical properties of sealants: An in vitro study. Int J Clin Pediatr Dent. 2015;8(3):196-201. Doi: https://doi.org/10.5005/jp-journals-10005-1312. 
14. Garcia IM, Rodrigues SB, Souza Balbinot G, Visioli F, Leitune VCB, Collares FM. Quaternary ammonium compound as antimicrobial agent in resin-based sealants. Clin Oral Investig. 2020;24(2):77784. Doi: https://doi.org/10.1007/s00784-019-02971-4.

15. Cocco AR, Cuevas-Suárez CE, Liu Y, Lund RG, Piva E, Hwang G. Anti-biofilm activity of a novel pit and fissure self-adhesive sealant modified with metallic monomers. Biofouling. 2020;36(3):245-55. Doi: https://doi.org/10.1080/08927014 .2020 .1748603 .

16. Shinonaga Y, Arita K, Nishimura T, Chiu SY, Chiu HH, Abe $\mathrm{Y}$, et al. Effects of porous-hydroxyapatite incorporated into glass-ionomer sealants. Dent Mater J. 2015;34(2):196-202. Doi: https://doi.org/10.4012/dmj.2014-195.

17. Rajabnia R, Ghasempour M, Gharekhani S, Gholamhoseinnia S, Soroorhomayoon S. Anti-Streptococcus mutans property of a chitosan: Containing resin sealant. J Int Soc Prev Community Dent. 2016;6(1):49-53. Doi: https://doi. org/10.4103/2231-0762.175405.

18. Garcia IM, Rodrigues SB, Leitune VCB, Collares FM. Antibacterial, chemical and physical properties of sealants with polyhexamethylene guanidine hydrochloride. Braz Oral Res. 2019;33:1-9. Doi: https://doi.org/10.1590/18073107bor-2019.vol33.0019.

19. Monteiro JC, Stürmer M, Garcia IM, Melo MA, Sauro S, Leitune VCB, et al. Dental sealant empowered by 1,3,5-Tri acryloyl hexahydro-1,3,5-triazine and $\alpha$ - tricalcium phosphate for anti-caries application. Polymers (Basel). 2020;12(4):895. Doi: https://doi.org/10.3390/polym12040895.

20. Tufanaru C, Munn Z, Aromataris E, Campbell J, Hopp L. Systematic reviews of effectiveness. In: Aromataris E, Munn $\mathrm{Z}$, editors. JBI manual for evidence synthesis [Internet]. The
Joanna Briggs Institute; 2020 [cited 2022 Feb 1]. Available from: https://synthesismanual.jbi.global/.

21. Mahapoka E, Arirachakaran P, Watthanaphanit A, Rujiravanit $\mathrm{R}$, Poolthong $\mathrm{S}$. Chitosan whiskers from shrimp shells incorporated into dimethacrylatebased dental resin sealant. Dent Mater J. 2012;31(2):273-9. Doi: https://doi. org/10.4012/dmj.2011-071.

22. Hosseinnejad M, Jafari SM. Evaluation of different factors affecting antimicrobial properties of chitosan. Int $\mathrm{J}$ Biol Macromol. 2016;85:467-75. Doi: http://doi.org/10.1016/j. ijbiomac.2016.01.022.

23. Nikolaidis A, Vouzara T, Koulaouzidou E. Pit and fissure nanocomposite sealants reinforced with organically modified montmorillonite: A study of their mechanical properties, surface roughness and color stability. Dent Mater J. 2020;39(5):773-83. Doi: https://doi.org/10.4012/dmj.2019-214.

24. Hasan AMHR, Sidhu SK, Nicholson JW. Fluoride release and uptake in enhanced bioactivity glass ionomer cement ("glass carbomerTM") compared with conventional and resin-modified glass ionomer cements. J Appl Oral Sci. 2019;27:1-6.

25. Okuyama K, Matsuda Y, Yamamoto H, Tamaki Y, Saito T, Hayashi M, et al. Fluorine distribution from fluoride-releasing luting materials into human dentin. Nucl Instrum Methods Phys Res B. 2019;456:16-20. Doi: https://doi. org/10.1016/j.nimb.2019.06.047

26. Yasuhiro M, Katsushi O, Hiroko Y, Hisanori K, Masashi K, Takahiro S, et al. Fluorine uptake into the human enamel surface from fluoride-containing sealing materials during cariogenic $\mathrm{pH}$ cycling. Nucl Instrum Methods Phys Res B. 2015;348:156-9. Doi: http://doi.org/10.1016/j. nimb.2015.01.062. 